\title{
Synthesis and evaluation of new pyrrolo[2,1-c][1,4]benzodiazepine hybrids linked to a flavone moiety
}

\author{
Ahmed Kamal, ${ }^{\text {* }}$ R. Ramu, ${ }^{\mathrm{a}}$ G. B. Ramesh Khanna, ${ }^{\mathrm{a}}$ Ajit Kumar Saxena, \\ M. Shanmugavel ${ }^{b}$, and Renu Moti Pandita ${ }^{b}$ \\ ${ }^{a}$ Division of Organic Chemistry, Indian Institute of Chemical Technology, \\ Hyderabad 500 007, India \\ ${ }^{b}$ Division of Pharmacology, Regional Research Laboratory, \\ Jammu 180 001, India \\ E-mail: ahmedkamal@iict.res.in
}

\begin{abstract}
In honor of Dr. A.V. Rama Rao on the occasion of his $70^{\text {th }}$ birthday
(received 10 Sep 04; accepted 31 Oct 04; published on the web 12 Nov 04)
\end{abstract}

\begin{abstract}
Pyrrolo[2,1-c][1,4]benzodiazepine hybrids linked to a flavone ring system have been designed, synthesized and evaluated for their biological activity. Flavone has been tethered to the C8 position of pyrrolobenzodiazepine through alkanedioxy spacers of varying lengths. These new type of hybrids exhibit significant DNA minor groove binding ability in comparison to the naturally occurring DC-81 and appreciable in vitro cytotoxicity.
\end{abstract}

Keywords: Pyrrolobenzodiazepines, flavones, cytotoxicity, DNA-binding

\section{Introduction}

In recent years there is much interest in the design and development of DNA interactive molecules that can bind to DNA in a sequence selective manner. In spite of enormous efforts to design synthetic DNA intercalators, very few molecules are in clinical usage that exhibit sequence selectivity. The synthesis of small molecules which exhibit DNA sequence selectivity is of immense importance for targeting the rapid growth of tumour cells.

The pyrrolo[2,1-c][1,4]benzodazepines (PBDs) are a group of naturally occurring antitumour antibiotics produced by various Streptomyces species and examples of which include anthramycin, tomaymycin, sibiromycin and DC-81. The formation of a covalent bond in the minor groove of DNA by nucleophilic attack of 2-amino group of a guanine base to form an aminal linkage to $\mathrm{C}-11$ is responsible for the biological activities of PBDs. ${ }^{1}$ Studies like X-ray and DNA foot-printing on the covalent DNA-PBD adducts have demonstrated a high sequence 
specificity for GC-rich DNA regions in particular, for Pu-G-Pu motifs. ${ }^{2}$ A large number of structurally modified PBDs have been prepared and evaluated for their biological activity, particularly their antitumour and DNA binding potential. ${ }^{3}$ A recently developed PBD dimer with C2-exomethylene substitution (SJG-136) has been selected for clinical trials (Figure 1). ${ }^{4}$ The PBDs have been used to attach ethylenediamine tetra acetic acid (EDTA), ${ }^{5}$ epoxide, ${ }^{6}$ pyrrole and imidazole polyamide ${ }^{7-9}$ and cyclopropaindole ${ }^{10,11}$ moieties, which have exhibited sequence selective DNA-cleavating and cross linking properties. Recently, we have been involved in the development on new synthetic strategies ${ }^{12}$ for the preparation of PBD ring systems and also in the design of structurally modified PBDs and their hybrids. ${ }^{13}$ In this pursuit some novel PBD hybrids and conjugates have been prepared by linking the PBD moiety to other DNA interactive compounds through suitable linkers.

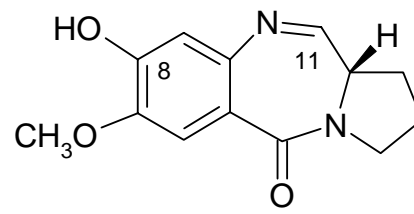

DC - 81

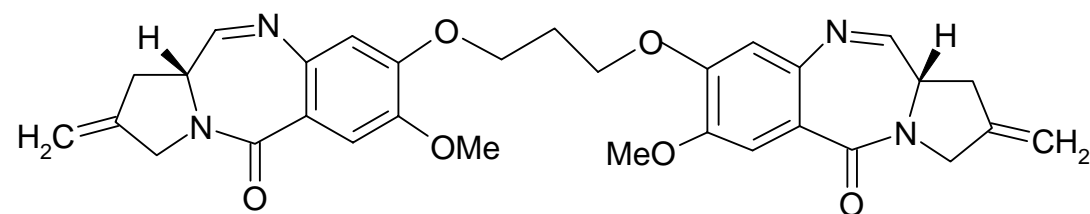

SJG - 136

Several flavonoid natural products have recently attracted attention as novel inhibitors of virus-associated reverse transcriptase. ${ }^{14}$ These flavonoid derivatives also inhibit various cellular DNA polymerases by binding to the double stranded nucleic acid template-primer or by competing with it for a site on the enzyme. The DNA intercalation contributes to the cytotoxicity of the flavonoids. ${ }^{15}$ In literature some flavonoids have been examined to induce enzymatic breakage by mammalian topoisomerase II. ${ }^{16}$ Additionally the cytotoxic effects of flavonoids have demonstrated promising cytotoxicity against some selected human tumour cell lines. Taking advantage of the DNA interactive property of flavone moiety, it was considered of interest to link it to the PBD ring system through different alkane spacers for the preparation of new hybrids of PBD and evaluation of their DNA binding property as well as in vitro anticancer potential.

\section{Results and Discussion}

The precursor (2S)- $N$-[4-(n-bromoalkyloxy)-5-methoxy-2-nitrobenzoyl]-pyrrolidine-2-carboxaldehyde diethyl thioacetal 1a-c has been prepared following our previously described procedure. ${ }^{13 a}$ Etherification of 6-hydroxy flavone by 1a-c gives the desired intermediate 2a-c. This nitrothioacetal has been reduced with $\mathrm{SnCl}_{2} \cdot 2 \mathrm{H}_{2} \mathrm{O}$ to give 3a-c. The deprotection of the thioacetal group afforded the desired compounds $4 \mathbf{a}-\mathbf{c}$ (Scheme). 


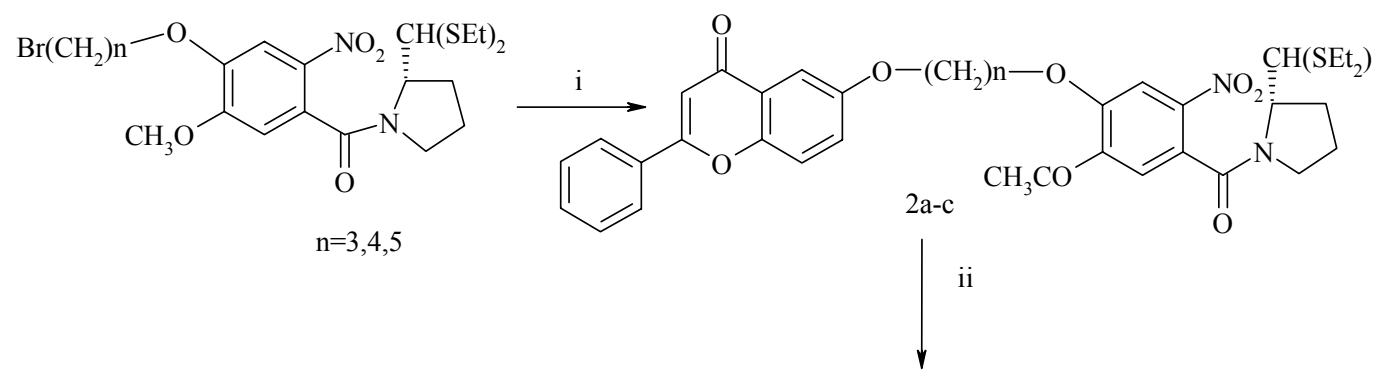

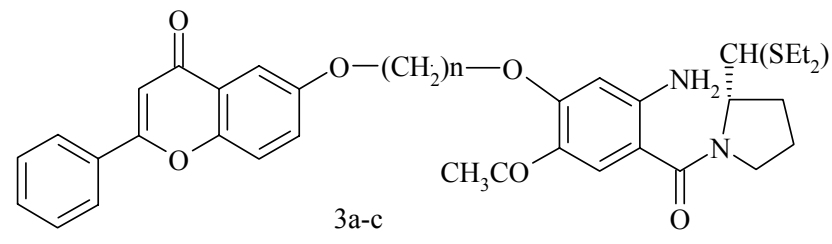<smiles>COc1cc2c(cc1O[14CH3])N=C[C@@H]1CCCN1C2=O</smiles>

Scheme 1. Reagents and conditions: (i) 6-hydroxyflavone, $\mathrm{K}_{2} \mathrm{CO}_{3}$, acetonitrile, reflux, $24 \mathrm{~h}$; (ii) $\mathrm{SnSl}_{2}$. $2 \mathrm{H}_{2} \mathrm{O}$, methanol, reflux, $5 \mathrm{~h}$; (iii) $\mathrm{HgCl}_{2}, \mathrm{CaCO}_{3}$, acetonitrile/ $\mathrm{H}_{2} \mathrm{O}$, r.t., $12 \mathrm{~h}$.

The DNA binding ability for these hybrids has been examined by using thermal denaturation assay with calf thymus (CT) DNA. ${ }^{17}$ Studies have been carried out at [DNA]/[ligand] molar ratio of $5: 1$. The increase in helix melting temperature $\left(\Delta T_{m}\right)$ has been examined after $0 \mathrm{~h}$ and $18 \mathrm{~h}$ of incubation at $37^{\circ} \mathrm{C}$ (Table 1). Interestingly, the compounds $\mathbf{4 a}$ and $\mathbf{4 c}$ elevates the helix melting temperature of CT-DNA by $6.2{ }^{\circ} \mathrm{C}$ and $2.6{ }^{\circ} \mathrm{C}$ after incubation for $18 \mathrm{~h}$ at $37{ }^{\circ} \mathrm{C}$. On the other hand, the naturally occurring DC-81 exhibits a $\Delta T_{\mathrm{m}}$ of $0.7^{\circ} \mathrm{C}$. This demonstrates that these PBDflavone conjugates have significant DNA binding ability as illustrated in Table 1. The results also demonstrate that increasing chain length from three to five reduces the DNA binding affinity. 
Table 1. Thermal denaturation data for flavone-PBD hybrids with CT-DNA

\begin{tabular}{ccc}
\hline Compound & \multicolumn{2}{c}{ Induced $\Delta T_{\mathrm{m}}{ }^{\circ} \mathrm{C}$ after incubation at $37{ }^{\circ} \mathrm{C}$} \\
\cline { 2 - 3 } & $0 \mathrm{~h}$ & $18 \mathrm{~h}$ \\
\hline 4a & 3.8 & 6.2 \\
4b & 1.6 & 1.8 \\
4c & 2.1 & 2.6 \\
DC-81 & 0.3 & 0.7 \\
\hline
\end{tabular}

For CT-DNA alone at $\mathrm{pH} 7.00 \pm 0.01, T_{\mathrm{m}}=69.8{ }^{\circ} \mathrm{C} \pm 0.01$ (mean value from 10 separate determinations), all $\Delta T_{\mathrm{m}}$ values are $\pm 0.1-0.2{ }^{\circ} \mathrm{C}$. For a $1: 5$ molar ratio of $[\mathrm{PBD}] /[\mathrm{DNA}]$, where CT-DNA concentration $=100 \mu \mathrm{M}$ and ligand concentration $=20 \mu \mathrm{M}$ in aqueous sodium phosphate buffer [10 mM sodium phosphate + 1 mM EDTA, pH $7.00 \pm 0.01]$.

Primarily, compounds 4a-c have been evaluated for their in vitro cytotoxicity in selected human cancer cell lines of colon (HT-29, HCT-15), lung (A-549, HOP-62), cervix (SiHa) origin by using sulforhodamine B (SRB) method. ${ }^{18}$ The results are expressed as percent of cell growth inhibition determined relative to that of untreated control cells (Table 2). Usually, when the concentration of the compound solution is $10^{-6} \mathrm{~mol} / \mathrm{L}$, the inhibition of the solution is more than $50 \%$, and then compound is considered as an effective agent. According to this standard, it has been observed from Table 2 that 4a exhibit a strong effect to HT-29, HCT-15, HOP-62 cell lines and compound 4c suppressing HCT-15 and A-549 cell growth by $69 \%$ and $63 \%$. The comparison of the data in Table 2 reveals the importance of an alkane spacer. As the alkane spacer increases from three to four the growth inhibition activity has decreased. This observation has been supported by thermal denaturation studies.

Table 2. The percentage growth inhibition data for flavone-PBD hybrids

\begin{tabular}{cccccc}
\hline \multirow{2}{*}{ Compd } & \multicolumn{5}{c}{ Cell lines } \\
\cline { 2 - 6 }$(\mathrm{mol} / \mathrm{L})$ & HT-29 & HCT-15 & A-549 & HOP-62 & SiHa \\
\cline { 2 - 6 } & $10^{-4} 10^{-5} 10^{-6}$ & $10^{-4} 10^{-5} 10^{-6}$ & $10^{-4} 10^{-5} 10^{-6}$ & $10^{-4} 10^{-5} 10^{-6}$ & $10^{-4} 10^{-5} 10^{-6}$ \\
\hline $\mathbf{4 a}$ & 918776 & a 466 & 92 a a & a 9373 & a 5249 \\
4b & 886831 & a 6449 & 90 a a & a 7912 & a 6018 \\
4c & 917850 & a 6869 & 915263 & a 8546 & a 4213 \\
\hline
\end{tabular}

a: not tested

In conclusion, we report the synthesis, DNA binding ability and in vitro cytotoxicity of the new PBD-flavone hybrids. These results show that an increase in linker chain length reduces the DNA binding affinity and in vitro growth inhibition of certain cancer cell lines. One of the hybrids with three carbon chain spacer (4a) exhibited significant DNA binding affinity as well as in vitro cytotoxicicty. 


\section{Experimental Section}

General Procedures. Reaction progress was monitored by thin-layer chromatography (TLC) using $\mathrm{GF}_{254}$ silica gel with fluorescent indicator on glass plates. Visualization was achieved with UV light and iodine vapour unless otherwise stated. Chromatography was performed using Acme silica gel (100-200 and 60-120 mesh). The majority of reaction solvents were purified by distillation under nitrogen from the indicated drying agent and used fresh: dichloromethane (calcium hydride), tetrahydrofuran (sodium benzophenone ketyl), methanol (magnesium methoxide) and acetonitrile (calcium hydride).

${ }^{1} \mathrm{H}$ NMR spectra were recorded on Varian Gemini $200 \mathrm{MHz}$ spectrometer using tetramethylsilane (TMS) as an internal standard. Chemical shifts are reported in parts per million (ppm) downfield from tetramethylsilane. Spin multiplicities are described as s (singlet), br $\mathrm{s}$ (broad singlet), d (doublet), $\mathrm{t}$ (triplet), q (quartet), $\mathrm{m}$ (multiplet). Coupling constants are reported in Hertz (Hz). Mass spectra obtained using a FAB-MS spectrophotometer.

(2S)-N-4-[3-(2-Phenyl-4-oxo-4H-[1]benzopyran-6-yloxy)propoxy]-5-methoxy-2-nitrobenzoyl pyrrolidine-2-carboxaldehyde diethyl thioacetal (2a). To a solution of (2S)- $N$-[4-(3bromopropoxy)-5-methoxy-2-nitrobenzoyl) pyrrolidine-2-carboxaldehyde diethyl thioacetal (1a) $(521 \mathrm{mg}, 1 \mathrm{mmol})$ in dry acetonitrile $(30 \mathrm{~mL})$ was added anhydrous $\mathrm{K}_{2} \mathrm{CO}_{3}(552 \mathrm{mg}, 4 \mathrm{mmol})$ and 6-hydroxy flavone $(238 \mathrm{mg}, 1 \mathrm{mmol})$. The reaction mixture was refluxed for $24 \mathrm{~h}$. The potassium carbonate was removed by filtration and the solvent was evaporated under vacuum, the crude product was purified by column chromatography (ethyl acetate-hexane 6:4) to afford the compound 2a as a yellow oil. (584 mg, 86\%). ${ }^{1} \mathrm{H} \mathrm{NMR}\left(\mathrm{CDCl}_{3}\right): \delta 1.28-1.40(\mathrm{~m}, 6 \mathrm{H}), 1.70-$ $2.45(\mathrm{~m}, 6 \mathrm{H}), 2.62-2.85(\mathrm{~m}, 4 \mathrm{H}), 3.12-3.30(\mathrm{~m}, 2 \mathrm{H}), 3.95(\mathrm{~s}, 3 \mathrm{H}), 4.32(\mathrm{t}, 4 \mathrm{H}), 4.60-4.70(\mathrm{~m}, 1 \mathrm{H})$, $4.82(\mathrm{~d}, 1 \mathrm{H}), 6.78(\mathrm{~s}, 2 \mathrm{H}), 7.24-7.30(\mathrm{~m}, 1 \mathrm{H}), 7.46-7.60(\mathrm{~m}, 5 \mathrm{H}), 7.70(\mathrm{~s}, 1 \mathrm{H}), 7.85-7.95(\mathrm{~m}, 2 \mathrm{H})$. FABMS $679\left(\mathrm{M}^{+}\right)$, Calcd for $\mathrm{C}_{35} \mathrm{H}_{38} \mathrm{~N}_{2} \mathrm{O}_{8} \mathrm{~S}_{2}$ : C, 61.93; H, 5.64; N, 4.13, S, 9.45; found: C, 61.85; H, 5.72; N, 4.07; S, 9.48.

(2S)-N-4-[4-(2-Phenyl-4-oxo-4H-[1]benzopyran-6-yloxy)butoxy]-5-methoxy-2-nitrobenzoyl pyrrolidine-2-carboxaldehyde diethyl thioacetal (2b). The compound $\mathbf{2 b}$ was prepared following the method described for the compound 2a, employing $\mathbf{1 b}$ (535 $\mathrm{mg}, 1 \mathrm{mmol}$ ) and the crude product was purified by column chromatography to afford the compound $\mathbf{2} \mathbf{b}$ as a yellow oil. (582 mg, 84\%). ${ }^{1} \mathrm{H}$ NMR $\left(\mathrm{CDCl}_{3}\right): \delta 1.28-1.40(\mathrm{~m}, 6 \mathrm{H}), 1.75-2.34(\mathrm{~m}, 8 \mathrm{H}), 2.65-2.84(\mathrm{~m}$, $4 \mathrm{H}), 3.18-3.30(\mathrm{~m}, 2 \mathrm{H}), 3.95(\mathrm{~s}, 3 \mathrm{H}), 4.15-4.26(\mathrm{~m}, 4 \mathrm{H}), 4.62-4.70(\mathrm{~m}, 1 \mathrm{H}), 4.82(\mathrm{~d}, 1 \mathrm{H}), 6.77(\mathrm{~s}$, 2H), 7.22-7.28 (m, 1H), 7.45-7.58 (m, 5H), $7.62(\mathrm{~s}, 1 \mathrm{H}), 7.88-7.94(\mathrm{~m}, 2 \mathrm{H})$. FABMS $693\left(\mathrm{M}^{+}\right)$, Calcd for $\mathrm{C}_{36} \mathrm{H}_{40} \mathrm{~N}_{2} \mathrm{O}_{8} \mathrm{~S}_{2}$ : C, 62.41; H, 5.82; N, 4.04, S, 9.25; found: C, 62.52; H, 5.88; N, 3.97; S, 9.28 .

(2S)-N-4-[5-(2-Phenyl-4-oxo-4H-[1]benzopyran-6-yloxy)pentyloxy]-5-methoxy-2-nitrobenzoyl pyrrolidine-2-carboxaldehyde diethyl thioacetal (2c). The compound 2c was prepared following the method described for the compound 2a, employing 1c (549 mg, $1 \mathrm{mmol}$ ) and the crude product was purified by column chromatography to afford the compound 2c as a yellow oil. 
(593 mg, 84\%). ${ }^{1} \mathrm{H}$ NMR $\left(\mathrm{CDCl}_{3}\right): \delta$ 1.30-1.40 (m, 6H), 1.70-2.32 (m, 10H), 2.65-2.85 (m, 4H), 3.18-3.30 (m, 2H), $3.96(\mathrm{~s}, 3 \mathrm{H}), 4.08-4.16(\mathrm{~m}, 4 \mathrm{H}), 4.62-4.70(\mathrm{~m}, 1 \mathrm{H}), 4.82(\mathrm{~d}, 1 \mathrm{H}), 6.78(\mathrm{~s}, 2 \mathrm{H})$, 7.22-7.30 (m, 1H), 7.45-7.55 (m, 5H), $7.62(\mathrm{~s}, 1 \mathrm{H}), 7.88-7.96(\mathrm{~m}, 2 \mathrm{H})$. FABMS $707\left(\mathrm{M}^{+}\right)$, Calcd for $\mathrm{C}_{37} \mathrm{H}_{42} \mathrm{~N}_{2} \mathrm{O}_{8} \mathrm{~S}_{2}$ : C, 62.87; H, 5.99; N, 3.96, S, 9.07; found: C, 62.82; H, 6.05; N, 3.92; S, 9.11. (2S)-N-4-[3-(2-Phenyl-4-oxo-4H-[1]benzopyran-6-yloxy)propoxy]-5-methoxy-2-aminobenzoyl pyrrolidine-2-carboxaldehyde diethyl thioacetal (3a). The compound 3a (679 mg, 1 mmol) dissolved in methanol $(20 \mathrm{~mL})$ and added $\mathrm{SnCl}_{2} .2 \mathrm{H}_{2} \mathrm{O}(1.13 \mathrm{gr}, 5 \mathrm{mmol})$ was refluxed for $5 \mathrm{~h}$. The reaction mixture was cooled and the methanol was evaporated under vacuum and the residue was carefully adjusted to $\mathrm{pH} 8$ with saturated $\mathrm{NaHCO}_{3}$ solution and then extracted with ethyl acetate $(2 \times 30 \mathrm{~mL})$. The combined organic phase was washed with brine $(15 \mathrm{~mL})$, dried over anhydrous $\mathrm{Na}_{2} \mathrm{SO}_{4}$ and evaporated under vacuum to afford the amino diethyl thioacetal 3a as yellow oil (506 mg, 78\%) and this was directly used in the next step.

(2S)-N-4-[4-(2-Phenyl-4-oxo-4H-[1]benzopyran-6-yloxy)butoxy]-5-methoxy-2-

aminobenzoyl pyrrolidine-2-carboxaldehyde diethyl thioacetal (3b). The compound $3 \mathbf{b}$ was prepared following the method described for the compound 3a, employing the compound $\mathbf{2 b}$ (693 $\mathrm{mg}, 1 \mathrm{mmol})$ to afford the amino diethyl thioacetal $3 \mathbf{b}$ as a yellow oil $(510 \mathrm{mg}, 77 \%)$.

(2S)- $N$-4-[5-(2-Phenyl-4-oxo-4H-[1]benzopyran-6-yloxy)pentyloxy]-5-methoxy-2-aminobenzoyl pyrrolidine-2-carboxaldehyde diethyl thioacetal (3c). The compound 3c was prepared following the method described for the compound 3a, employing the compound 2c (707 mg, 1 mmol) to afford the amino diethyl thioacetal 3c as a yellow oil (528 $\mathrm{mg}, 78 \%)$.

7-Methoxy-8-\{3-[2-phenyl-4-oxo-4H-[1]benzopyran-6-yloxy]propoxy\}-(11aS)-1,2,3,11atetrahydro-5H-pyrrolo[2,1-c][1,4]benzodiazepin-5-one (4a). A solution of amino thioacetal 3a (649 mg, $1 \mathrm{mmol}), \mathrm{HgCl}_{2}(597 \mathrm{mg}, 2.2 \mathrm{mmol})$ and $\mathrm{CaCO}_{3}(240 \mathrm{mg}, 2.4 \mathrm{mmol})$ in acetonitrilewater (4:1) was stirred slowly at room temperature for $12 \mathrm{~h}$, until TLC indicate the complete disappearance of starting material. The reaction mixture was diluted with ethyl acetate $(30 \mathrm{~mL})$ and filtered through a celite. The clear yellow organic supernatant was extracted with ethyl acetate $(2 \times 20 \mathrm{~mL})$. The organic layer was washed with saturated $\mathrm{NaHCO}_{3}(20 \mathrm{~mL})$, brine $(20$ $\mathrm{mL}$ ) and the combined organic phase was dried over anhydrous $\mathrm{Na}_{2} \mathrm{SO}_{4}$. The organic layer was evaporated under vacuum and the crude product was purified by column chromatography $(5 \%$ $\left.\mathrm{CHCl}_{3}-\mathrm{MeOH}\right)$ to afford the compound $4 \mathbf{a}$ as a pale yellow solid $(273 \mathrm{mg}, 52 \%)$. This material was repeatedly evaporated from $\mathrm{CHCl}_{3}$ in vacuum to generate the imine form, m.p.: 73-75 ${ }^{\circ} \mathrm{C},{ }^{1} \mathrm{H}$ NMR $\left(\mathrm{CDCl}_{3}\right): \delta 1.98-2.12(\mathrm{~m}, 3 \mathrm{H}), 2.22-2.45(\mathrm{~m}, 3 \mathrm{H}), 3.50-3.88(\mathrm{~m}, 3 \mathrm{H}), 3.95(\mathrm{~s}, 3 \mathrm{H}), 4.24-$ $4.37(\mathrm{~m}, 4 \mathrm{H}), 6.77(\mathrm{~s}, 1 \mathrm{H}), 6.81(\mathrm{~s}, 1 \mathrm{H}), 7.20-7.30(\mathrm{~m}, 1 \mathrm{H}), 7.42-7.65(\mathrm{~m}, 7 \mathrm{H}), 7.85-7.95(\mathrm{~m}, 2 \mathrm{H})$. IR 2931, 2851, 1625, 1458, 1365, 1256, 1194, $1025 \mathrm{~cm}^{-1}$, FABMS 525 (M+1), Calcd for $\mathrm{C}_{31} \mathrm{H}_{28} \mathrm{~N}_{2} \mathrm{O}_{6}$ : C, 70.98; H, 5.38; N, 5.34; found: C, 70.82; H, 5.46; N, 5.22.

7-Methoxy-8-\{4-[2-phenyl-4-oxo-4H-[1]benzopyran-6-yloxy]butoxy\}-(11aS)-1,2,3,11atetrahydro-5H-pyrrolo[2,1-c][1,4]benzodiazepin-5-one (4b). The compound $4 \mathrm{~b}$ was prepared following the method described for the compound 4a employing $3 \mathbf{b}$ (663 $\mathrm{mg}, 1 \mathrm{mmol})$, to afford the compound $\mathbf{4 b}$ as a pale yellow solid $(291 \mathrm{mg}, 54 \%)$, m.p.: $72-74{ }^{\circ} \mathrm{C},{ }^{1} \mathrm{H} \mathrm{NMR}\left(\mathrm{CDCl}_{3}\right): \delta$ 1.95-2.40 (m, 8H), 3.56-3.85 (m, 3H), 3.92 (s, 3H), 4.05-4.25 (m, 4H), $6.75(\mathrm{~s}, 2 \mathrm{H}), 7.20-7.30$ (m, 
1H), 7.40-7.66 (m, 7H), 7.85-7.95 (m, 2H). IR 2930, 2849, 1626, 1458, 1363, 1256, 1194, $1024 \mathrm{~cm}^{-1}$, FABMS $539(\mathrm{M}+1)$, Calcd for $\mathrm{C}_{32} \mathrm{H}_{30} \mathrm{~N}_{2} \mathrm{O}_{6}$ : C, 71.36; H, 5.61; N, 5.20; found: C, 71.58; H, 5.38; N, 5.32 .

7-Methoxy-8-\{5-[2-phenyl-4-oxo-4H-[1]benzopyran-6-yloxy]pentyloxy\}-(11aS)-1,2,3,11atetrahydro-5H-pyrrolo[2,1-c][1,4]benzodiazepin-5-one (4c). The compound 4c was prepared following the method described for the compound 4a employing 3c (677 mg, $1 \mathrm{mmol})$, to afford the compound $4 \mathrm{c}$ as a pale yellow solid $(298 \mathrm{mg}, 54 \%)$, m.p.: $68-70{ }^{\circ} \mathrm{C},{ }^{1} \mathrm{H}$ NMR $\left(\mathrm{CDCl}_{3}\right): \delta$ $1.92-2.45(\mathrm{~m}, 10 \mathrm{H}), 3.54-3.85(\mathrm{~m}, 3 \mathrm{H}), 3.95(\mathrm{~s}, 3 \mathrm{H}), 4.10-4.32(\mathrm{~m}, 4 \mathrm{H}), 6.75(\mathrm{~s}, 2 \mathrm{H}), 7.20-7.32$ (m, 1H), 7.42-7.66 (m, 7H), 7.85-7.95 (m, 2H). IR 2933, 2851, 1626, 1458, 1364, 1256, 1197 , $1023 \mathrm{~cm}^{-1}$, FABMS $553(\mathrm{M}+1)$, Calcd for $\mathrm{C}_{33} \mathrm{H}_{32} \mathrm{~N}_{2} \mathrm{O}_{6}$ : C, 71.72; H, 5.84; N, 5.07; found: C, $71.85 ; \mathrm{H}, 5.65 ; \mathrm{N}, 5.25$.

Thermal denaturation studies. Compounds were subjected to thermal denaturation studies with duplex-form calf thymus DNA (CT-DNA) using an adaptation of a reported procedure. Working solutions in aqueous buffer $\left(10 \mathrm{mM} \mathrm{NaH} \mathrm{PO}_{4} / \mathrm{Na}_{2} \mathrm{HPO}_{4}, 1 \mathrm{mM} \mathrm{Na} 2 \mathrm{EDTA}\right.$, pH 7.00+0.01) containing CT-DNA $(100 \mu \mathrm{m}$ in phosphate) and the PBD $(20 \mu \mathrm{m})$ were prepared by addition of concentrated PBD solutions in $\mathrm{MeOH}$ to obtain a fixed [PBD]/[DNA] molar ratio of 1:5. The DNA-PBD solutions were incubated at $37{ }^{\circ} \mathrm{C}$ for $0,18,36$ and $48 \mathrm{~h}$ prior to analysis. Samples were monitored at $260 \mathrm{~nm}$ using a Beckman DU-7400 spectrophotometer fitted with high performance temperature controller, and heating was applied at $1{ }^{\circ} \mathrm{C} \min ^{-1}$ in the $40-90{ }^{\circ} \mathrm{C}$ range. DNA helix coil transition temperatures $\left(T_{\mathrm{m}}\right)$ were obtained from the maxima in the $\left(\mathrm{d} A_{260}\right) / \mathrm{d} T$ derivative plots. Results are given as the mean \pm standard deviation from three determinations and are corrected for the effects of $\mathrm{MeOH}$ co-solvent using a linear correction term. Druginduced alterations in DNA melting behaviour are given by: $\Delta T_{\mathrm{m}}=T_{\mathrm{m}}(\mathrm{DNA}+\mathrm{PBD})-T_{\mathrm{m}}$ (DNA alone), where the $T_{\mathrm{m}}$ value for the PBD-free CT-DNA is $69.0 \pm 0.01$. The fixed [PBD]/[DNA] ratio used did not result in binding saturation of the host DNA duplex for any compound examined.

In vitro evaluation of cytotoxic activity. In vitro cytotoxicity was evaluated using human cancer cell lines HT-29, HCT-15, A-549,HOP-62 and SiHa. Viable cells were seeded in growth medium into 96-well microtiter plates and allowed to attach overnight. A protocol of $48 \mathrm{~h}$ continuous drug exposure was used, ${ }^{18 \mathrm{a}}$ and a sulforhodamine B (SRB) protein assay was used to estimate cell viability or growth. ${ }^{18 b}$

\section{Acknowledgements}

Two of the authors R.R, G.B.R.K are grateful to CSIR, New Delhi for the award of research fellowship. 


\section{References}

1. (a) Thurston, D. E. In Molecular Aspects of Anticancer Drug DNA Interactions; Neidle, S.; Waring, M. J.; Eds.; McMillan:London, 1993; p 54. (b) Tender, M. D.; Korman, S. Nature 1963, 199, 501. (c) Hurley, L. H.; Petrusek, R. L. Nature 1979, 282, 529.

2. Kopka, M. L.; Goodsell, D. S.; Baikalov, I.; Grzeskowiak, K.; Cascio, D.; Dickerson, R. E. Biochemistry 1994, 33, 13593.

3. Kamal, A.; Rao, M. V.; Laxman, N.; Ramesh, G.; Reddy, G. S. K. Curr. Med. Chem. AntiCancer Agents. 2002, 2, 215.

4. Gregson, S. J.; Howard, P. H.; Hartley, J. A.; Brooks, N. A.; Adams, L. J.; Jenkins, T. C.; Kelland, L. R.; Thurston, D. E. J. Med. Chem. 2001, 44, 737.

5. Thurston, D. E.; Morris, S. J.; Hartley, J. A. Chem. Commun. 1996, 563

6. Wilson, S. C.; Howard, P. W.; Forrow, S. M.; Hartley, J. A.; Adams, L. J.; Jenkins, T. C.; Kelland, L. R.; Thurston, D. E. J. Med. Chem. 1999, 42, 4028.

7. Baraldi, P. G.; Balboni, G.; Cacciari, B.; Guiotto, A.; Manfredini, S.; Romagnoli, R.; Spalluto, G.; Thurston, D. E.; Howard, P. W.; Bianchi, N.; Rutigliano, C.; Mischiati, C.; Gambari, R. J. Med. Chem. 1999, 42, 5131.

8. Damayanthi, Y.; Reddy, B. S. P.; Lown, J. W. J. Org. Chem. 1999, 64, 290.

9. Kumar, R.; Lown, J. W. Org. Biomol. Chem. 2003, 1, 3327.

10. Zhou, Q.; Duan, W.; Simmons, D.; Shayo, Y.; Raymond, M. A.; Dorr, R. T.; Hurley, L. H. J. Am. Chem. Soc. 2001, 123, 4865.

11. Tercel, M.; Stribbling, S. M.; Sheppard, H.; Siim, B. G.; Wu, K.; Pullen, S. M.; Botting, K. J.; Wilson, W. R.; Denny, W. A. J. Med. Chem. 2003, 46, 2132.

12. (a) Kamal, A.; Laxman, E.; Reddy, P. S. M. M. Tetrahedron Lett. 2000, 41, 7743. (b) Kamal, A.; Reddy, G. S. K.; Raghavan, S. Bioorg. Med. Chem. Lett. 2001, 13, 387. (c) Kamal, A.; Reddy, P. S. M. M.; Reddy, D. R. Tetrahedron Lett. 2003, 44, 2557.

13. (a) Kamal, A.; Ramesh, G.; Laxman, N.; Ramulu, P.; Srinivas, O.; Neelima, K.; Kondapi, A. K.; Srinu, V. B.; Nagarajaram, H. M. J. Med.Chem. 2002, 45, 4679. (b) Kamal, A.; Reddy, B. S. N.; Reddy, G. S. K.; Ramesh, G. Bioorg. Med .Chem. Lett. 2002, 12, 1933. (c) Kamal, A.; Ramesh, G.; Ramulu, P.; Srinivas, O.; Rehana, T.; Sheelu, G. Bioorg. Med. Chem. Lett. 2003, 13, 3451. (d) Kamal, A.; Ramulu, P.; Srinivas, O.; Ramesh, G. Bioorg. Med. Chem. Lett. 2003, 13, 3517. (e) Kamal, A.; Srinivas, O.; Ramulu, P.; Ramesh, G.; Kumar, P. P. Bioorg. Med. Chem. Lett. 2003, 13, 3577. (f) Kamal, A.; Reddy, P. S. M. M.; Reddy, D. R. Bioorg. Med. Chem. Lett. 2004, 14, 2669.

14. (a) Ono, K.; Nakane, H.; Fukushima, M.; Chermann, J. C.; Barre-Sinoussi, F. Biochem. Biophys. Res. Commun. 1989, 160, 982. (b) Ono, K.; Nakane, H.; Fukushima, M.; Chermann, J. C.; Barre-Sinoussi, F. Eur. J. Biochem. 1990, 190, 469.

15. (a) Wang, T.C.; Zhao, Y.L.; Liou, S. S. Helv. Chim. Acta. 2002, 85, 1382. (b) Chen, Y.L.; Chen, P.H.; Chung, C. H.; Li, K. C.; Jeng, H. Y.; Tzeng, C. C. Helv. Chim. Acta. 2003, 86, 778. 
16. Austin, C.A.; Patel, S.; Ono, K.; Nakane, H.; Fisher, L. M. Biochem. J. 1992, 282, 883.

17. Puvvada, M. S.; Hartley, J. A.; Jenkins, T. C.; Thurston, D. E. Nucleic Acids Res. 1993, 21, 3671.

18. Monks, A.; Scudiero, D.; Skehan, P.; Shoemaker, R.; Paull, K.; Vistica, D.; Hose, C.; Langley, J.; Cronise, P.; Wolff, A. V.; Goodrich, M. G.; Campbell, H.; Mayo, J.; Boyd, M. J. Natl. Cancer Inst. 1991, 83, 757. (b) Shekan, P.; Storeng, R.; Scudiero, D.; Monks, A.; McMahon, J.; Vistica, D.; Warren, J. T.; Bokesch, H.; Kenney, S.; Boyd, M. R. J. Natl. Cancer Inst. 1990, 82, 1107. 